Josef Veselý

\title{
Vliv sakrální architektury na urbanismus měst
}

Klíčová slova: Urbanismus; Církev; Město; Sakrální stavby.

Kontakt: josef.vesely@hotmail.com

Školitel: Karel Havliš

Tematický okruh: Urbanismus

The Influence of Church Architecture on Urbanism in Cities

Since the beginnings of urban development, church buildings have been integral parts of cities, integral parts of Central European urban societies. For most of the time the Church fulfilled not only its pastoral function, but also played an important economic and educational role. As a result, church buildings became centres around which urban societies were organised. 
Sakrální stavby jsou od počátku vývoje měst jejich nedílnou součástí. Nedílnou součástí života a fungování středoevropské městské společnosti. Po většinu doby církev zastávala nejen funkci pastorační, ale ve velké míře i funkci vzdělávací, hospodářskou a ekonomickou. Důsledkem toho se církevní stavby staly ohnisky organizace městské společnosti.

Tyto funkce a jejich společenský význam ovlivnily míru působení církve a jejích staveb na strukturu města. Církevní stavby (jak sakrální, tak profánní) byly těžišti urbánní struktury a častokrát celou městskou strukturu formovaly a také vhodně doplňovaly. $V$ neposlední řadě měly sakrální stavby majoritní vliv na obraz města, na to, jak bylo vnímáno, jak bylo zobrazováno a jak na něj bylo nahlíženo. Tento vliv je i dnes, po několika staletích, čitelný a pro celkový obraz města stěžejní.

Stavitelé sakrálních staveb přinášeli do středoevropského prostředí nové formy, a sakrální stavby byly často průlomové a do značné míry ovlivňovaly stavební kulturu celého sídla. Sakrální stavby přinášely nové stavební postupy a technologie, nové pohledy na formování prostoru uvnitř i vně.

Krystalická podoba městských sídel a jejich urbanismu na jižní Moravě a v Dolním Rakousku nese podobné charakteristické rysy. Jejich vzájemné porovnání a hledání podobností a rozdílů mezi nimi může vést k pochopení základních vazeb mezi církevními stavbami a společností a jejich principů. A také $\mathrm{k}$ možnostem aplikace a adaptace těchto principů v současné době, kdy množství církevních staveb těžko hledá využití a jejich společenský význam je minimální.

Vybrané příklady měst ilustrují míru vlivu církevních staveb na formování urbánní struktury. Jsou mezi nimi zastoupeny jak dolnorakouské, tak jihomoravské př́klady, a to v různých měřítcích. Od malých měst, jejichž podobu ovlivnila jediná, zato výrazná stavba, po města velká. Po sídla, ve kterých působilo množství církevních společenství a řádů a ve kterých byl vliv jejich staveb na obraz města výrazně pestřejší.

\section{SOUPIS ZDROJU゚}

KRÜGER, Kristina. Řády a kláštery: 2000 let křestanského umění a kultury. Editor Rolf Toman. V Praze: Slovart, 2008, 431 s. ISBN 978-80-7391-121-8.

VONDRUŠKOVÁ, Alena a Vlastimil VONDRUŠKA. Církev: průvodce českou historií. Vyd. 1. Praha: Vyšehrad, 2014, 199 s. Průvodce českou historií. ISBN 978-80-7429-441-9. 


\section{FOTOGRAFIE}

[1] AUTOR NEUVEDEN. Centrum Vodárna [online]. [cit. 26.5.2015]. Dostupné z: http://centrumvodarna.cz/uploads/images/areal/hist_4.jpg. Poznámka: Plány Thomase Weebera z roku 1815 jsou uloženy ve sbírkách Státního okresního archivu ve Znojmě a Jihomoravského muzea ve Znojmě, černobílé v originále, barevné v kopii - originál v makovici radniční věže.

[2] AUTOR NEUVEDEN. Foto historie [online]. [cit. 26.5.2015]. Dostupné z: http://www.fotohistorie.cz/image.jpg.ashx?photoID=36191\&photoType $=0$ 


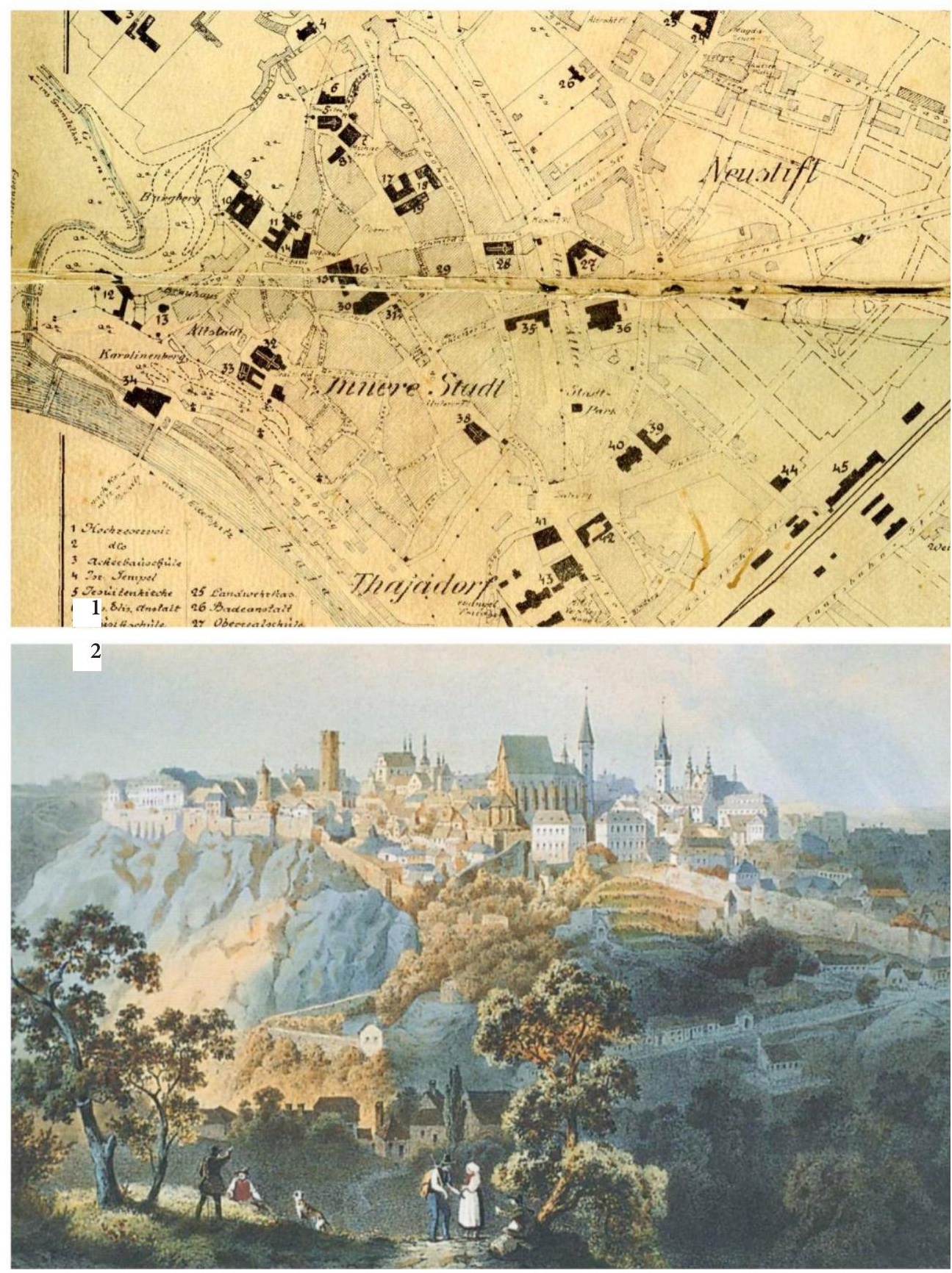

